\title{
Anomaly or Augury? Global Food Prices Since 2007
}

\section{Richard King}

\begin{abstract}
This article reviews the dynamics of global food prices since the food crisis of 2007-08, the extent to which international prices have influenced national prices and poverty and wellbeing outcomes, and considers whether this exceptional period represents an anomaly or likely signals future episodes of food price volatility. It finds that although some factors that contributed to recent events have eased considerably, some significant drivers remain structural threats to future food security. There is little reason to be confident that recent reductions in food prices and volatilities augur well for the food security or wellbeing of those living on low and precarious incomes in the future.
\end{abstract}

\section{Introduction}

Since the global food crisis of 2007-08, prices of staple foods have been higher and more volatile than in recent decades. There are many contributory causes, on both the supply and demand sides, and these have been the subject of intense debate over recent years. There have equally been many responses aiming to dampen volatility and ameliorate the wider economic and wellbeing impacts of food price volatility. As this IDS Bulletin goes to press, prices are once again on the decline and the violent volatility witnessed in recent years has diminished.

This article first reviews the macro-level trends and causes of recent upheavals in global food prices, as well as policy responses to them. Second, it examines how these signals affect food prices paid in local markets, and looks at some consequential generalised poverty and food security outcomes. Finally, it considers whether these dynamics represent an anomaly in long-term trends or are harbingers of the shape of food markets in the future.

\section{International food prices: trends, causes, policy responses}

2.1 Trends

By one measure, over the whole of the twentieth century food prices declined by an average of 0.7 per cent per year despite a significant increase in demand testament to improving yields and ever greater volumes of production (Dobbs et al. 2013; Sumner 2009).

However, in early 2007 prices of major internationallytraded food commodity prices soared, dramatically accelerating an increase in prices noticeable from the turn of the century. As measured by the Food and Agriculture Organization of the United Nations' (FAO) composite food price index, by June 2008 prices were 81 per cent higher than two years earlier in nominal terms. Despite the long-term trend, the absolute levels of these prices were not unprecedented; in real terms similar levels were reached during the 1970s in the wake of that decade's oil crisis, albeit for a briefer period. There is some debate about how best to measure real food prices; Dorward (2011), for example, has noted that deflating by measures that are derived from expenditure patterns of wealthier countries or populations, such as the World Bank's Manufactures Unit Value Index, as used by the FAO real price index, ${ }^{1}$ may not accurately capture low-income consumers' experiences. Nonetheless, the recent price spikes represent a dramatic departure from the trend over the previous 20 years of relatively stable prices, and the amplitude and duration of the recent episode of elevated prices is significant in both real and nominal terms (see Figure 1).

The changes in these composite indices reflect the aggregate movements in the prices of the underlying cereal, oil, meat, dairy and sugar food commodities that they capture. While each has a different profile, all have experienced significant turbulence in recent years. Among staple food crops that provide much of the dietary energy to consumers in developing countries, international wheat and maize prices more or less trebled in 2008 compared with 2005 prices, and rice prices more than doubled (see 


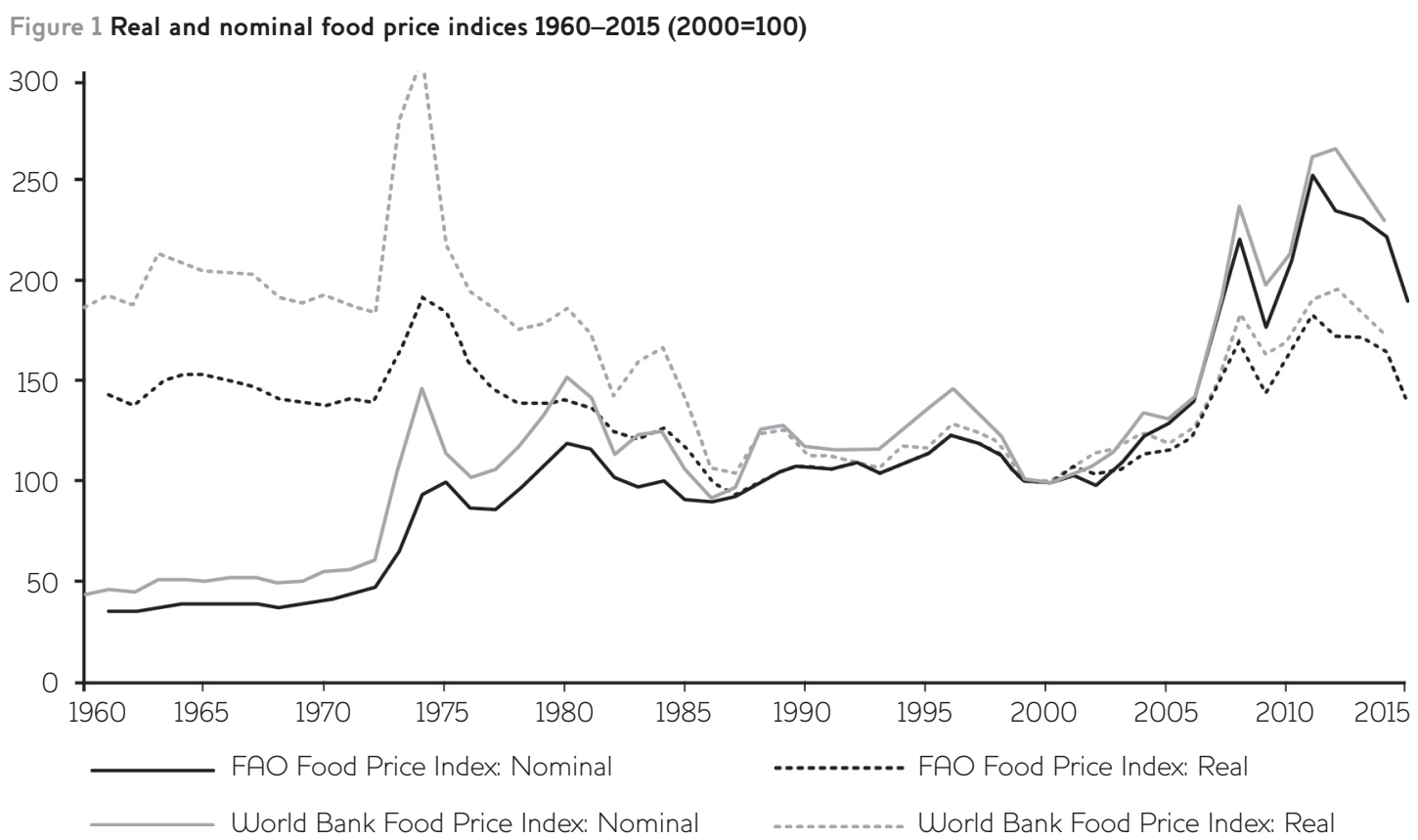

Source World Bank (2015) and FAO (2015a).

Figure 2 Indexed nominal staple food prices 2005-14: \$/mt (2005=100)

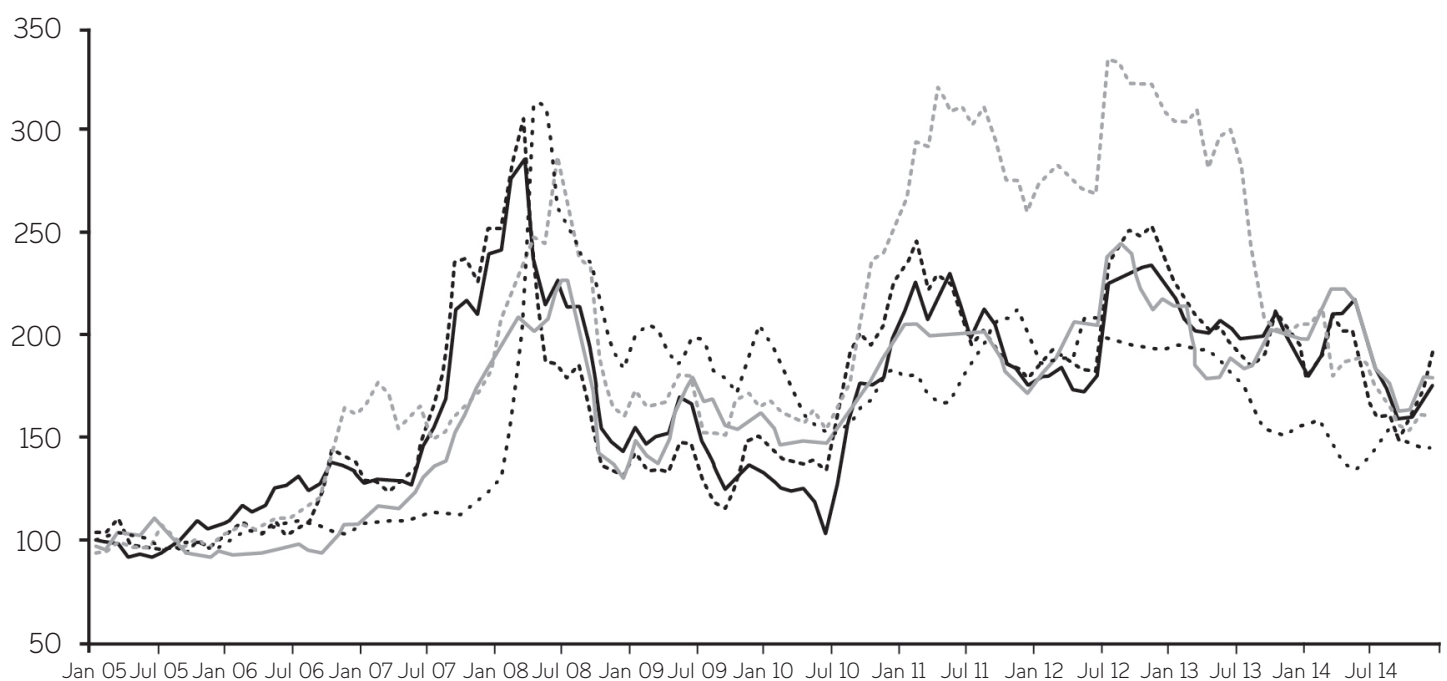

Figure 2). After a dramatic fall in prices in 2009, the subsequent period was equally volatile, especially for maize prices. However, since April 2014 composite food indices and the international prices of staple crops have fallen steadily to, by the beginning of
2015, levels not seen since July 2010, posing the question of whether we are coming to the end of an unusually turbulent episode in international food markets, or whether this is temporary respite prior to further episodes of price escalations and volatility. 


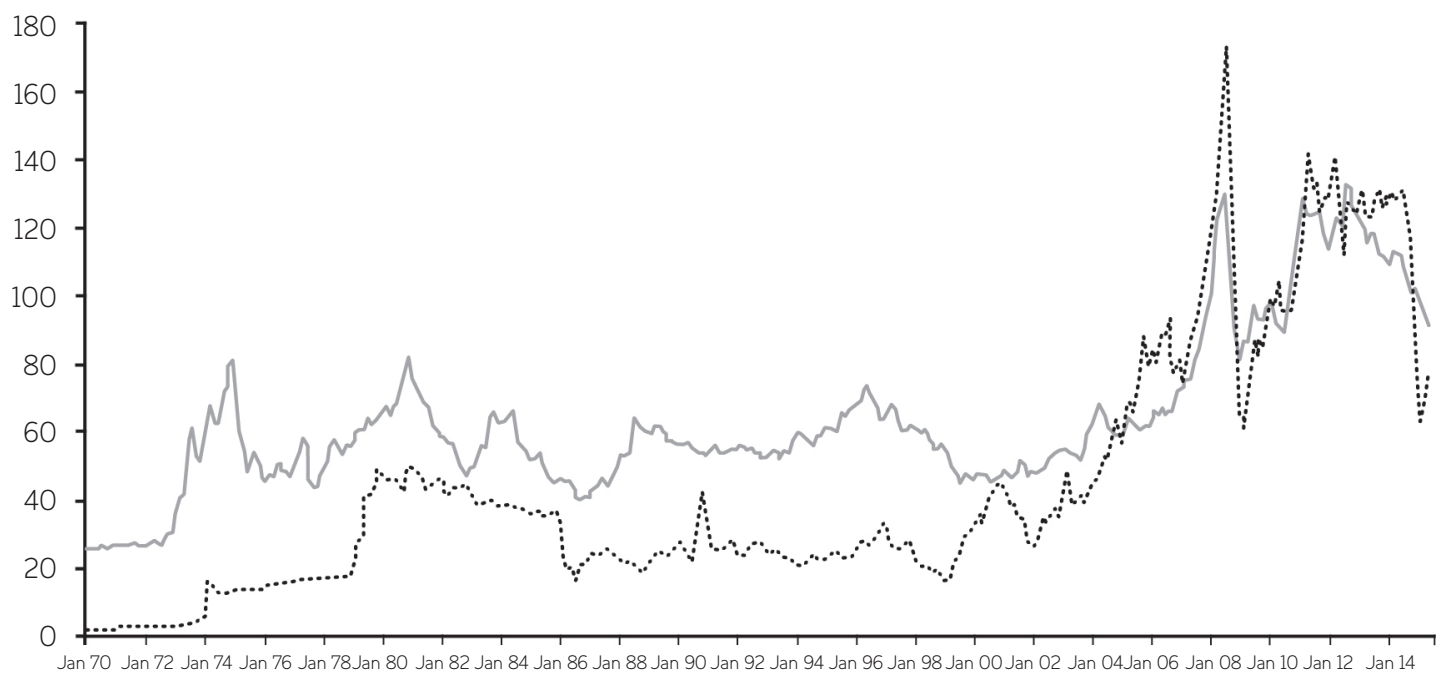

Energy Food

Source World Bank (2015).

Although these monthly price series give a quick visual impression of month-to-month volatility, the International Food Policy Research Institute (IFPRI) has devised a more statistically robust approach to assessing volatility in staple food markets. The model uses daily returns on the Chicago Board of Trade to estimate 95 per cent conditional quantiles and contrasts these estimates with realised returns over the previous 60 days. An instance of extreme volatility is recorded where returns exceed the quantiles, and a test is performed to verify whether or not the number of days characterised by excess volatility is statistically different from what would have been expected. Although there have been isolated extreme daily returns for all price series considered (hard and soft wheats, maize, soybean and rice) since 2012, these high levels of returns have not sustained themselves for extended periods in a statistically significant manner, in the way that they did prior to 2013 (IFPRI 2015; Martins-Filho pers. comm. 2015).

\subsection{Causes}

Many factors have contributed to the determination of recent international food price movements; some are short-term phenomena, others are more structural in nature. Drawing on Wiggins and Keat's (2013) schema, factors are divided into those that enabled, triggered and exacerbated price spikes. The relative importance of these drivers is subject to live and contested debates, but there is broad consensus that the following elements have at least some bearing on contemporary food price movements.

\subsubsection{Enabling factors}

Agricultural slowdown, demand increase

As a result of dwindling agricultural investment and bringing ever more marginal lands into production, global aggregate growth in yields plummeted to just over 1 per cent between 1990 and 2007 from an average of 2 per cent per year between 1970 and 1990. This decline is projected to continue over the next decade to a fraction of 1 per cent. The share of land devoted to agriculture has also peaked (Oxfam 2011). Combined with the lowest stock-to-use ratios since the 1970s, this slowdown in production growth resulted in agricultural markets very exposed to supply shocks. At the same time, demand increased due to demographic pressures and shifting dietary preferences. Global populations continue to grow and diets of new middle-income consumers in many emerging economies are becoming increasingly Westernised, resulting in ever more demand for meat and dairy products. This means that cereal and oil crops do not only have to feed more humans but more livestock too, resulting in a less calorically-efficient conversion of crop energy to human energy intake.

Fuel

Crops are facing increasing demand not only as sources of food and feed, but as fuel too (sugar and maize for bioethanol, and vegetable oils for biodiesel). As agricultural crops have become increasingly substitutable for other sources of energy, and as fossil fuels have become more and 
more important inputs to agricultural production (as fertilisers and fuel for agricultural machinery), so too has the fate of food prices become ever more intertwined with energy prices. The commodities supercycle of the early twenty-first century resulted in a very close correlation between energy and fuel prices (see Figure 3).

\subsubsection{Short-term triggers}

Supply shocks

Given the very tight supply conditions, significant climatic shocks including droughts and floods in major grain-producing regions played a significant role in sending food prices soaring. In 2006, Australia and Canada were particularly badly affected. In 2012, maize and soybeans in the midwest of the United States were subjected to the most severe drought and extreme heat since the 1950s; there was also a severe drought in the Black Sea region. Underlying these shocks are the enabling factors of ecological degradation and a changing climate, increasing both the frequency and intensity of such events as well as altering seasons and harvests in more insidious ways.

\section{Biofuel mandates}

Biofuel production has increased dramatically since the beginning of the century, accelerated by regulations in the EU, USA and Canada requiring minimum biofuel contents in gasoline and diesel, in effect producing fairly inelastic demand. The US is a major supplier to global maize markets but in 2010 nearly 40 per cent of US maize production went into vehicle engines rather than people's stomachs (Oxfam 2011). In 2013 the UN High Level Panel of Experts (HLPE) asserted, 'Everything else being equal, the introduction of a rigid biofuel demand does affect food commodity prices', and that 'in the last few years (since 2004) of short-term commodity food price increase [sic], biofuels did play an important role' (HLPE 2013: 14).

\subsubsection{Exacerbating factors}

\section{Trade policies}

Knee-jerk export bans and taxes, import subsidy reductions, and mass public procurements in the immediate wake of price increases, while providing some short-run security for national supplies, acted as accelerants on price movements, pushing prices higher and reducing trust in international markets.

\section{Financialisation}

Between 2005 and 2011, the value of financial investments in commodity-related assets increased almost nine times to US $\$ 450$ billion, more than
US $\$ 100$ billion of which was invested in agricultural commodities (Dobbs et al. 2013). The degree to which the level and stability of agricultural spot prices are affected by high volumes and high frequencies of speculative capital entering and exiting agricultural futures markets is highly contested. It is beyond the scope of this article to unpick the debate, beyond noting that there does seem to be some level of consensus that increased participation by non-commercial actors such as index funds, swap dealers and money managers in financial markets probably acted to amplify shortterm price swings and could have contributed to the formation of price bubbles in some situations' (FAO et al. 2011: 12).

\subsection{Policy responses}

Policy responses to the initial global price spike in 2007-08 by both national governments and international agencies were largely myopic and uncoordinated. At least 25 food-exporting countries either banned or increased taxes on exports as a result of the global shock, further destabilising international markets. These trade measures have historically tended, at least initially, to be more effective at stabilising domestic prices than building-up buffer stocks, but tend to ultimately lead to a 'typical prisoner's dilemma where the world market is trapped in a non-cooperative equilibrium' (Gouel 2013: 34). Many importing countries reduced import taxes, largely ineffectually, and concerns about scarcity of supply led to mass public procurement from international markets. It rapidly became apparent that information and communication about stock levels and production forecasts were very patchy and delayed, which contributed to uncertainty and rash decision-making (FAO et al. 2011).

In many cases, producers were given support in meeting the rising input costs of feed and fertilisers. Consumer support was offered in the form of cash transfers and direct food assistance, but in many places the rapidity and magnitude of price increases quickly eroded the purchasing power of both mechanisms, which in any case tended to favour urban consumers more than their rural counterparts (Pinstrup-Anderson 2015). Additionally, many countries lacked sufficient pre-existing administrative infrastructure to roll out these schemes with any degree of effectiveness (ibid.).

A few years on there is growing consensus that effective responses should likely comprise some mix of the following elements. 


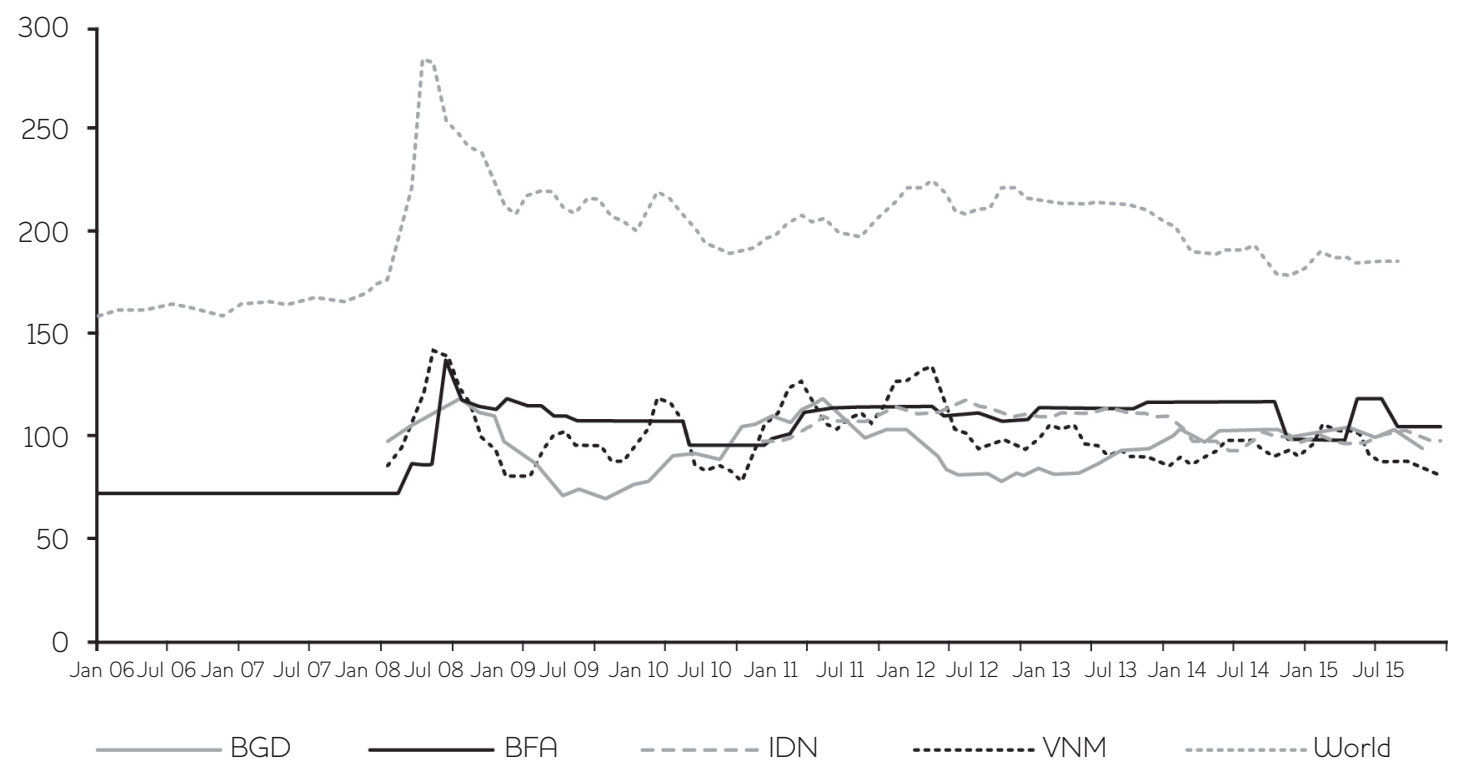

Figure 4b Indexed nominal world and national maize prices 2006-15

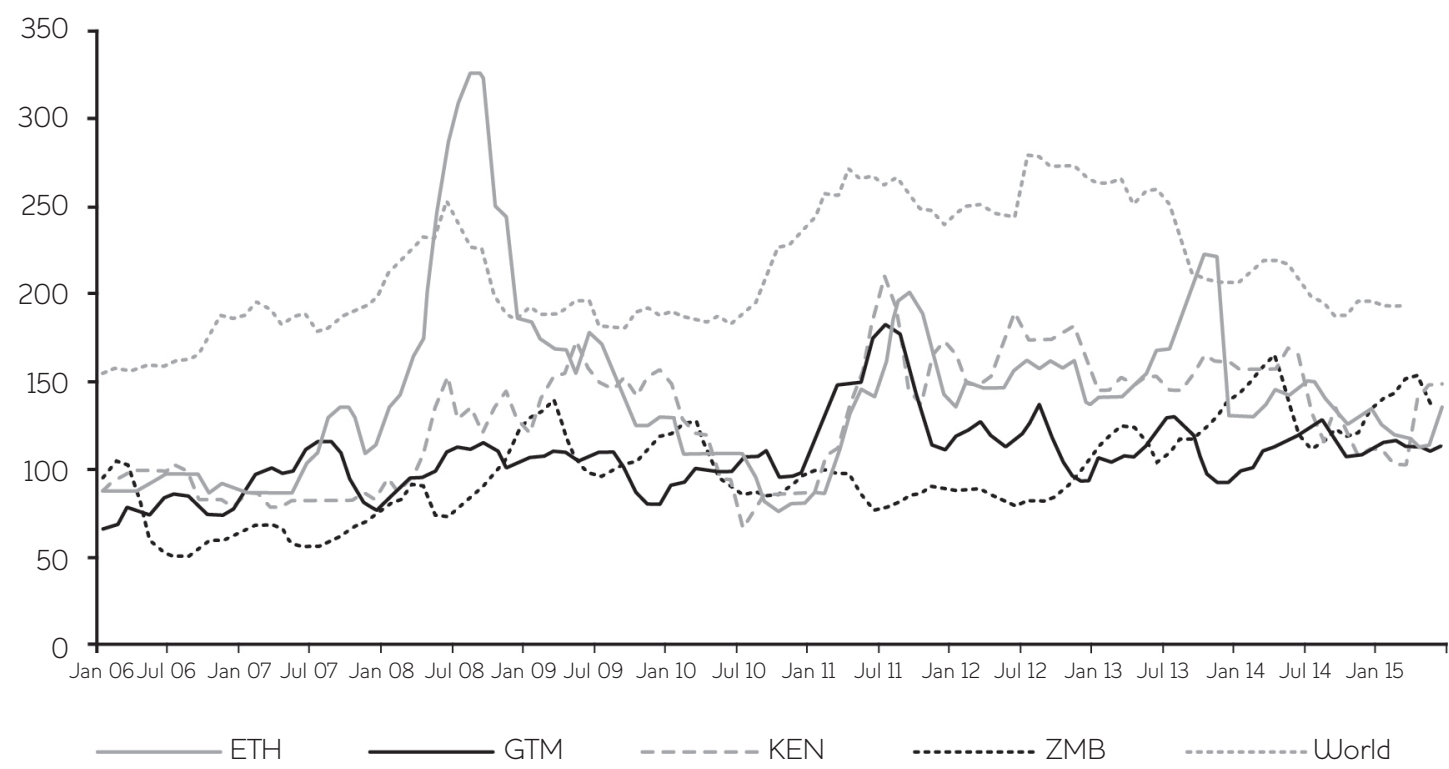

\subsubsection{Better market information and cooperation}

It is unlikely that resorting to self-interested unilateral trade measures in times of market uncertainty will ever be entirely eliminated, but better and more timely market information can certainly help. The Agricultural Market Information System (AMIS), established as part of the Action Plan on Food Price Volatility at the G20 meeting in June 2011, aims to improve global market transparency. It includes a Rapid Response Forum to 'promote early discussion among decision-level officials about critical market conditions to encourage the coordination of policies and the development of common strategies' (AMIS 2015a). AMIS has been operating since September 2012, and while still fledgling, improved information-sharing and transparency may have helped in avoiding panicked unilateral trade policies in response to the soaring prices in July 2012. However, a 2015 review of progress notes (alongside successes) inadequate data transfers from participating 


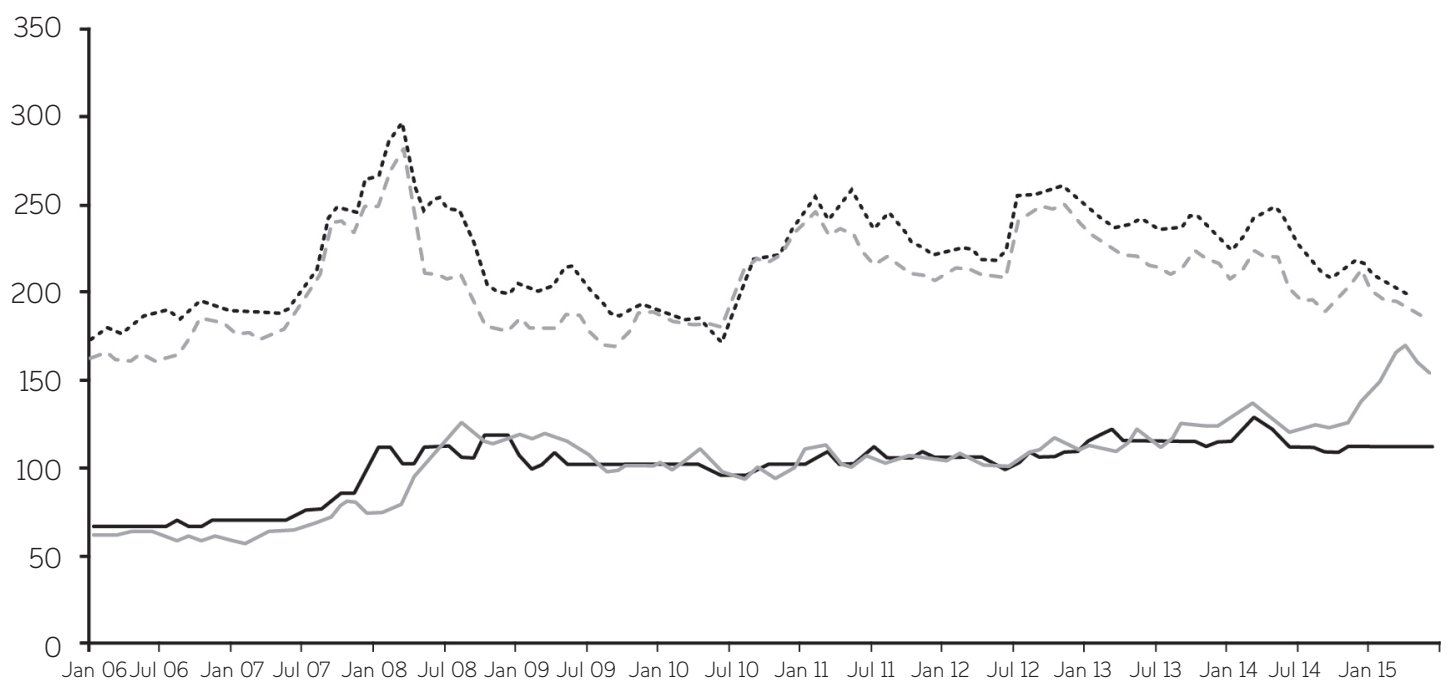

BOL PAK World, hard wheat

Notes 2010=100, world prices offset by 50 points for clarity.

Original Nominal Price Series:

Bangladesh, Dhaka, Rice (coarse), Retail (US\$/kg)

Burkina Faso, Ouagadougou, Rice (imported), Wholesale (CFA Franc/100kg)

Indonesia, National Average, Rice (medium quality), Retail (US\$/kg)

Vietnam, An Giang, Rice (20\% broken), Wholesale (US\$/kg)

World, Rice, Thailand, 5\%, \$/mt, nominal \$

Ethiopia, Addis Ababa, Maize, Wholesale (US\$/kg)

Guatemala, Guatemala City, Maize (white), Wholesale (US\$/kg)

Kenya, Nairobi, Maize, Wholesale (US\$/kg)

Zambia, National Average, Maize (white), Retail (Kwacha/17kg)

World, Maize, \$/mt, nominal \$

Bolivia, Cochabamba, Wheat (pelado), Wholesale (Boliviano/Spanish quintal (46kg))

Pakistan, Karachi, Wheat, Retail (US\$/kg)

World, Wheat, US, SRW, \$/mt, nominal \$

World, Wheat, US, HRW, \$/mt, nominal \$

Source World prices: World Bank (2015), National prices: FAO (2015b)

countries, with only five countries honouring their commitment to submit monthly forecasts of their crop balances (AMIS 2015b).

\subsubsection{Emergency food reserves}

Despite persisting questions about the effectiveness of widespread generalised buffer stocks, emergency food reserves that mitigate against short-run supply constraints appear to be a viable and vital mechanism to reduce the resilience of food markets to shocks. Managing these regionally may prove to be the most effective means of implementation (cf. FAO et al. 2011; Gouel 2013).

\subsubsection{Ex ante domestic social protection and safety net programmes}

Recent events have demonstrated that introducing ad hoc safety nets from scratch in response to shocks is frequently ineffectual. Equally, as the Life in a Time of Food Price Volatility research has revealed, 
where social protection programmes do exist they tend to be valued by beneficiaries both as a support mechanism and an overt demonstration that the government is doing something in response to price shocks. But for these to be successful they need to be geographically and economically scalable in times of crisis and they need to build on and complement people's own informal coping mechanisms rather than crowding-out or seeking to replace existing reciprocal agreements and social contracts.

\subsubsection{Control of financialisation of markets}

Both Europe and the US have introduced hard limits on commodity-derivatives speculation, capping the number of over-the-counter contracts in a particular commodity (including agricultural commodities) that can be held by a trader or group of traders. This prevents disproportionate concentration of resources, ensuring that speculators do not exert an excessive influence on spot prices. $^{2}$ Further reforms of increasing severity might include improving transparency of positions by bringing over-the-counter derivative transactions onto exchanges, restricting high frequency trading, imposing limits on the total amount of speculative money in agricultural markets, and restricting participation in futures markets to those with vested interests in the underlying agricultural commodities (Spratt 2013).

\subsubsection{Agricultural investment}

Perhaps the most positive outcome of recent price spikes has been renewed interest in investing in the productivity and resilience of developing country agriculture, reversing decades of neglect as a key economic sector. However, public investment in small-scale agriculture is still far short of where it needs to be to ensure a resilient sector and resilient rural households (Wise and Murphy 2012). Appropriate investment in small-scale agriculture and rural economies has the potential to improve food security through both reducing food price volatility and helping farmers and households to better cope when volatility does occur (FAO et al. 2011). However, there have also been significant large-scale speculative land acquisitions in lowincome countries with weak governance, which threaten to undermine the local population's access to land and food security.

\section{Local conditions and outcomes: price transmission and wellbeing}

Important as they are, the international market dynamics presented in the preceding section do not fully reflect the realities faced by consumers purchasing their food in domestic markets, or producers selling their produce into the same. This section considers how the linkages between international food prices and wellbeing are mediated.

\subsection{International price transmission}

Local market prices are unevenly influenced by international markets, but are also subject to local factors with little or no bearing on prices elsewhere, such as domestic policy measures and idiosyncratic supply shocks. Recent analysis of price transmissions from international to domestic cereal markets in developing countries suggests that, on average, approximately three-quarters of international price changes may be transmitted to domestic markets, and it takes six to seven months for half of an international price shock to be transmitted to local prices (Greb et al. 2012). ${ }^{3}$ However, there is significant variation around this mean depending on many factors including exchange rates (which possess their own dynamics, and which impact on border prices and are linked to local market prices through a variety of factors and mechanisms); reliance on food imports (which is related to national production and stock levels); transportation costs, especially for interior countries; physical infrastructure; government subsidies and trade-policy interventions, including, for example, import duties, export taxes and non-tariff barriers (World Bank 2012; Naylor and Falcon 2010; FAO et al. 2011).

Overall, domestic and global maize markets appear to have a below-average prevalence of 'cointegration', and rice markets have above-average prevalence. A study of the Tanzanian maize market found that regional markets exert more influence on domestic prices than do global prices (Baffes, Kshirsagar and Mitchell 2015). While most countries are wheat and maize price-takers, the determination of international rice prices is less clear. Regionally, domestic prices in African and Asian markets are less likely to be co-integrated with international prices (Greb et al. 2012). In sub-Saharan Africa, where domestic food price volatility is high, Minot (2012) found no evidence that these volatilities increased further from 2007 to 2010, despite the increasing volatility for international grain prices. However, Greb et al. (2012) found a general increase in domestic price volatility since July 2007 (even among prices that are not co-integrated with their international equivalents), and found domestic prices to be most volatile in East and West Africa, followed by Latin America. Generally, local market price volatility is greater than that in international markets (Zoyra et al. 2014). 
Table 1 Percentage change in the total cost of the food basket relative to the average prices for the same month over the last five years

\begin{tabular}{|c|c|c|c|c|c|c|c|}
\hline & 2013 Q2 & 2013 Q3 & 2013 Q4 & 2014 Q1 & 2014 Q2 & 2014 Q3 & 2014 Q4 \\
\hline BFA & 9 & 0 & 2 & 2 & 3 & -3 & 2 \\
\hline BGD & 5 & 9 & 13 & 13 & 25 & 22 & 17 \\
\hline BOL & 8 & 17 & 20 & 18 & 41 & 24 & 9 \\
\hline ETH & 16 & 15 & 25 & 20 & 38 & 38 & 39 \\
\hline GTM & 17 & 17 & 17 & 11 & 24 & 26 & 29 \\
\hline IDN & 20 & 18 & 17 & 16 & 24 & 20 & 21 \\
\hline KEN & 21 & 17 & 16 & 14 & 22 & 18 & 26 \\
\hline PAK & 13 & 17 & 17 & 19 & 39 & 30 & 26 \\
\hline VNM & & & & & -4 & 11 & -6 \\
\hline ZMB & 13 & 19 & 14 & 16 & 35 & 34 & 17 \\
\hline Low (< O\%) & & \multicolumn{2}{|c|}{ Moderate (0-5\%) } & \multicolumn{2}{|c|}{ High (5-10\%) } & \multicolumn{2}{|c|}{ Severe (> 10\%) } \\
\hline
\end{tabular}

Source WFP (2015).

There is also a question as to whether domestic prices respond to international market signals equally when prices are declining as they do when prices are rising. Some evidence at least suggests that local prices may be 'sticky' and remain elevated even when international prices are cooling off (Ghosh 2010).

As Figures 4a, 4b and 4c show, there are similarities but not direct correlations between international prices and prices in domestic markets for rice, maize and wheat, staple crops in the ten countries considered in the Life in a Time of Food Price Volatility research. In Zambian maize markets, for example, the removal of consumption and production subsidies in May 2013 had a major bearing on the subsequent escalation of national maize prices, in spite of global maize prices falling over the same period. Although only illustrative, this serves to demonstrate that the economic realities faced by people making purchases in local markets are affected by far more than the dynamics of international markets. These difficult purchasing decisions themselves and their impacts on people's overall food and nutritional security and general wellbeing are, in turn, mediated by far more than price dynamics alone, as other articles in this IDS Bulletin attest.

\subsection{Diverse food baskets}

Nutritious and satiating meals are not comprised singularly of staple carbohydrate-rich foodstuffs, but also of foods that meet protein, fat and micronutrient requirements. As the Life in a Time of Food Price Volatility research has demonstrated, people's personal preferences regarding the composition of their diets, and their abilities to source and consume foods that meet preferential and nutritional needs varies considerably.

But nowhere are food consumption costs and budgetary considerations determined by the price of one commodity alone. Quarterly World Food Programme (WFP) assessments of the changing costs of typical food baskets in the ten countries demonstrates that, as of the end of 2014, prices remained above their five-year averages everywhere except Vietnam, even if they have declined from quarter to quarter (see Table 1).

Food prices are also changing in the context of broader shifts in living costs and wages. Generalised inflation metrics are wholly unsatisfactory measures of living costs of people on low and precarious wages as their costs can vary significantly from the average, and securing sufficient income to cover costs can be a daily struggle rather than a smoothed monthly challenge. Nonetheless, Figure 5 gives a sense of generalised and food price inflation in the 


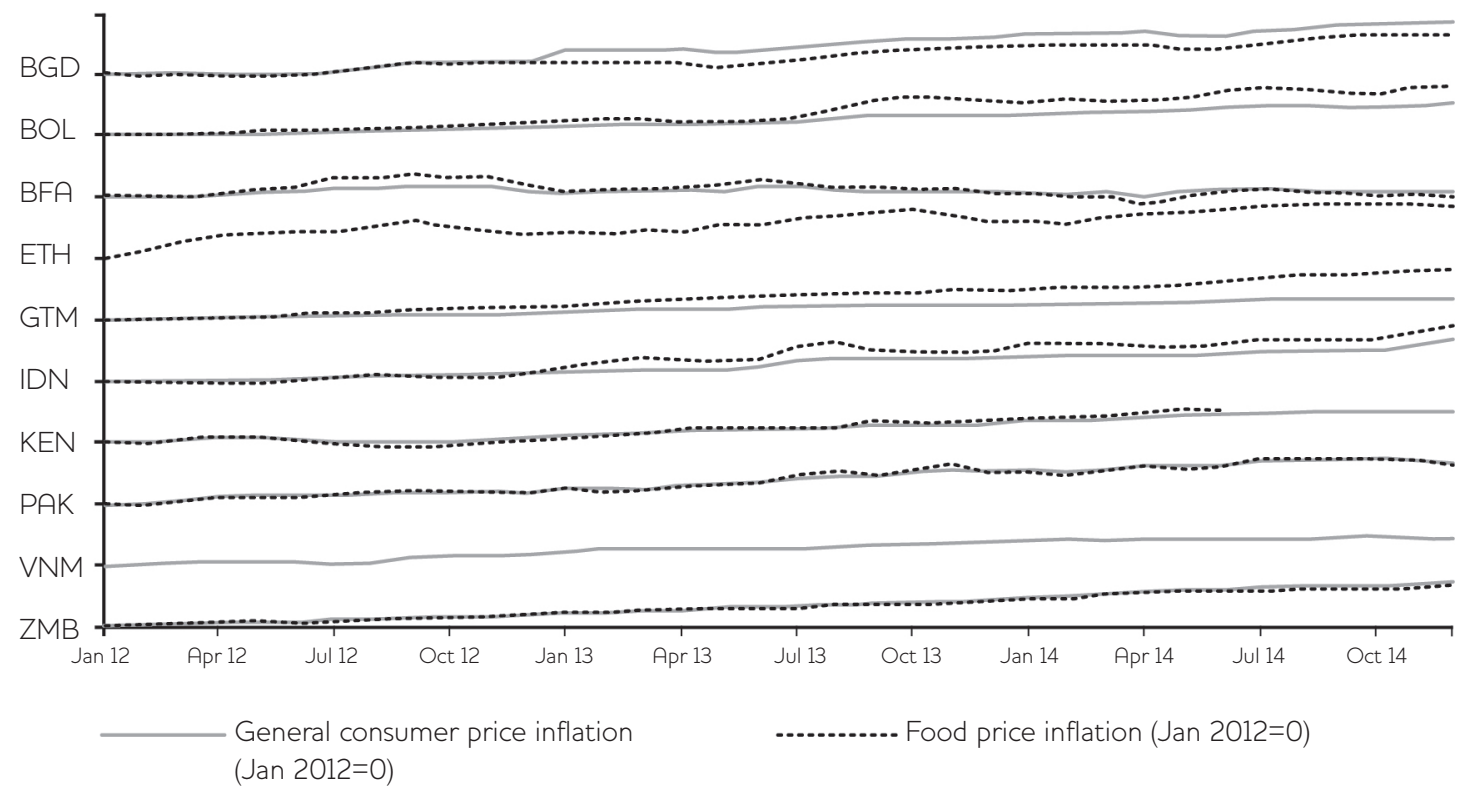

Life in a Time of Food Price Volatility countries since 2012. In some places, Bolivia, Guatemala and Indonesia, food prices have clearly driven up overall living costs, whereas in Bangladesh, food prices have risen more slowly than other costs.

Overall, we see a very mixed picture in terms of the levels and stability of food costs faced by consumers in recent years, driven and mediated to varying degrees by international market dynamics. Although these markets set the macro context in which national and household responses are formulated, they do not fully capture the lived realities in which decisions are taken and varying degrees of wellbeing are realised.

\subsection{Wellbeing outcomes}

Other articles in this issue of the IDS Bulletin give a rich picture of the context in which individuals and households are taking, or not taking, conscious and unconscious decisions that have a bearing on their own and their families' overall wellbeing and food and nutritional security, both short and long term. In some cases, food prices are clearly pre-eminent or significant contextual factors; in others the importance of food prices is less pronounced. But where food prices are contributory factors to personal and policy choices, they may have a bearing on decision-making either due to their absolute realised levels, or as a result of the uncertainty that volatility creates about future realities. Where sentiment is a driver in decision-making, this can create a reality of its own if individual and/or policy choices are made in expectation of an outcome, whether or not that actually materialises. For example, in the expectation of tight supply markets several exporting nations introduced export controls in 2008 and 2011 , precipitating similar actions elsewhere, spreading a collapse in confidence, and further constraining international supplies (Lee et al. 2012). Here we consider some of the aggregate outcomes for individuals' wellbeing in which food price dynamics, or suppositions about those dynamics, are implicated.

\section{Based on simulation models and data from 31} developing countries, Ivanic and Martin (2014) estimate the monetary poverty-inducing effects of price rises of varying magnitudes and various foods. They find, unsurprisingly, adverse implications of higher prices for poverty in the short run, even for farming households, many of whom are net consumers. However, the aggregate impacts over the longer term are more positive, though highly diverse. These modelled benefits are achieved as a result of wages and agricultural prices adjusting. It would be disingenuous, however, to suggest that the potential longer-term adjustments negate the short-term pain, as consumers on low incomes with little to no savings are not able to smooth their consumption in the same way that those with higher savings 
might. Equally the process of wage adjustment is not uniform or automatic, but often highly uneven and contested. Headey (2014), who also finds an empirical relationship between higher food prices and poverty reduction, acknowledges that such adjustments do not happen instantaneously and that the welfare of poor net consumers, particularly in urban areas, is significantly negatively affected by high food prices in the short term.

A review of the empirical evidence and simulation studies (DFID 2014) finds both positive and negative impacts of food price changes on poverty, but that low-income households benefiting from price rises are typically outnumbered by those losing out; in the short term both the prevalence and depth of poverty increase. The review suggests that 'secondround responses to food price increases such as upward pressure on unskilled rural wages and changes in household production decisions may reduce a welfare loss, but is not conclusive' (p4) - a complexity mirrored by the findings of the Life in a Time of Food Price Volatility research.

While an absolute rise in food prices over a sustained period may have potential benefits for poverty reduction and permit greater investment in agricultural and other rural sectors, it is less clear that volatility or rapid price adjustments have a positive impact over a similar time frame. Volatility creates uncertainty and risk premiums that can forestall effective planning and decision-making, resulting in opportunities for investment going unfulfilled, both at household and macroeconomic levels (cf. Cavalcanti et al. 2012; FAO et al. 2011). One might therefore expect excessive volatility to introduce a significant negative influence on higher prices' long-run poverty-reducing potential. However, focusing on five least-developed countries, Magrini, Opazo and Balié (2015) find that households would benefit more from preventing or limiting increases in cereal prices than from reducing their volatility, though they acknowledge that the impact of volatility in their study design is less observable owing to households' varying capacities to manage and cope with risk. They also find that price volatility harms the poorest households most, especially in urban areas, with significant differences between the poorest and the richest households.

But beyond impacts on direct monetary poverty, short-run price shocks can additionally lock-in long-term changes in wellbeing. For instance, decisions to migrate in search of additional or better paid work may be taken in response to immediate economic realities, but the consequences of those decisions, such as relationship breakdowns, may endure significantly longer than the initial galvanising situation. Equally, even short-lived disruptions to children's nutrient intakes can have lifelong impacts if they result in stunting or lower educational outcomes (Young Lives 2008). The impact on micro- and macro-nutrient intake, as opposed to pure caloric sufficiency, is important for food and nutritional security. A systematic review of the evidence on the effects of rising food prices

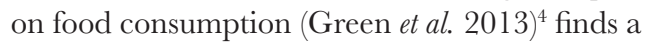
greater negative effect on food consumption in lower-income countries and in poorer households within countries. Across national wealth categories, it found food price rises were most likely to reduce demand for animal source foods such as meat, fish and dairy, with less impact on demand for dietary staples such as cereals, suggesting that dietary nutrient diversity is likely to be compromised before caloric intake, especially in developing nations. However, even in the relatively prosperous EU, where food consumption typically assumes a much smaller share of household spending than in lowerincome countries, there is evidence that higher retail food prices are associated with (moderately small) increases in the percentage of food-deprived households, even controlling for household sizes and disposable incomes (García-Germán, Bardají and Garrido 2015).

\section{Conclusions}

Are recent reductions in the levels and volatility of international food prices signalling an end to or a hiatus in the shocks of recent years? Although some contributory factors such as very tight stockto-use ratios and sky-high oil prices have eased considerably, and some positive developments have been made in market regulation and transparency, it is also true that some significant structural drivers remain spectres looming on the horizon, and investments in the resilience of populations and agricultures largely remain woefully inadequate. There is little to instil confidence that recent respites augur well for future food security and wellbeing in the medium term. Climatic shocks are only going to become more frequent and severe; demand and competition for resources are only going to intensify. Whether or not Malthus's ghost will end up haunting us, achieving food and nutritional security in this emerging context will not be straightforward, and it would be foolhardy to discount the prospect of future food supply shocks and squeezes of some sort well into the future. 
As we have seen, international food market dynamics are an important part of the context in which people on low and precarious incomes seek to fulfil their own and their families' food and nutritional security and wellbeing. But they are just one component among many. Prices in local markets where people buy, sell and barter for their food are additionally influenced by a multitude of idiosyncratic factors. Food prices may now assume a greater prominence

\section{Notes}

1 For further information see FAO (2013) and http://go.worldbank.org/SZXEODLF60.

2 In Europe this is via reform to the Markets in Financial Instruments Directive (MiFID); in the US the Commodity Futures Trading Commission (CFTC) has new authority under the 2010 DoddFrank financial regulation.

\section{References}

AMIS (2015a) The Rapid Response Forum, Agricultural Market Information System, www.amis-outlook. org/amis-about/forum/en/ (accessed 10 July 2015) AMIS (2015b) AMIS Progress and Activities: March 2014 to March 2015, Agricultural Market Information System, www.amis-outlook.org/fileadmin/user_ upload/amis/docs/Rapid_Response_Forum_4/ RRF_4_2015_2.pdf (accessed 10 July 2015)

Baffes, J.; Kshirsagar, V. and Mitchell, D. (2015) What Drives Local Food Prices? Evidence from the Tanzanian Maize Market, World Bank Policy Research Working Paper 7338, Washington DC: World Bank, www-wds.worldbank.org/external/ default/WDSContentServer/WDSP/IB/2015/0 6/26/090224b082f92116/1_0/Rendered/PDF/ What0drives0lo0nzanian0maize0market.pdf (accessed 10 July 2015)

Cavalcanti, Tiago V. de V.; Mohaddes, Kamiar and Raissi, Mehdi (2012) Commodity Price Volatility and the Sources of Growth, IMF Working Paper 12/12, Washington DC: IMF, www.imf.org/external/ pubs/cat/longres.aspx?sk $=25621.0 \% 0 \mathrm{a}$ (accessed 10 July 2015)

DFID (2014) Food Prices and Poverty: Agriculture and Growth Evidence Paper Series, UK Department for International Development, www.gov. uk/government/uploads/system/uploads/ attachment_data/file/318351/Food_prices_and_ poverty_final_.pdf (accessed 10 July 2015)

Dobbs, R.; Oppenheim, J.; Thompson, F.; Mareels, S.; Nyquist, S. and Sanghvi, S. (2013) Resource Revolution: Tracking Global Commodity Markets, McKinsey Global Institute, www.mckinsey.com/Insights/Energy_ Resources_Materials/Resource_revolution_ in people's decision-making, and sudden shifts can certainly catalyse changes in lives that endure well beyond the initial impetus. But people's life chances and circumstances are mediated and threatened by far more than food prices alone. Rarely is life in a time of food price volatility eased or bettered by these uncertain global dynamics, but rarely is life truly a result of global food price volatility.

3 Similarly, an analysis of the price spike of $1972-6$ found that domestic prices for 12 agricultural commodities in developing countries reflected just over half of the peak in world prices (Anderson and Nelgen (2010), cited in Naylor and Falcon (2010)).

4 Not limited to post-2007 episodes.

Tracking_global_commodity_markets (accessed 10 July 2015)

Dorward, A. (2011) Getting Real about Food Prices, CDPR Development Viewpoint 58, London: Centre for Development Policy and Research, School of Oriental and African Studies, www. soas.ac.uk/cdpr/publications/dv/file66348.pdf (accessed 10 July 2015)

FAO (2015a) Food Price Monitoring and Analysis Tool, Food and Agriculture Organization, www.fao. $\mathrm{org} /$ giews/pricetool/ (accessed 10 July 2015)

FAO (2015b) FAO Food Price Index, Food and Agriculture Organization, www.fao.org/ worldfoodsituation/foodpricesindex/en/ (accessed 10 July 2015)

FAO (2013) Food Outlook November 2013: Special Features, Food and Agriculture Organization, www.fao.org/fileadmin/templates/worldfood/ Reports_and_docs/Special_feature_FFPI_en.pdf (accessed 10 July 2015)

FAO, IFAD, IMF, OECD, UNCTAD, WFP, World Bank, WTO, IFPRI and UN HLTF (2011) Price Volatility in Food and Agricultural Markets: Policy Responses, Organisation for Economic Co-operation and Development, www.oecd.org/ tad/agricultural-trade/48152638.pdf (accessed 10 July 2015)

García-Germán, S.; Bardají, I. and Garrido, A. (2015) 'Analysis of Material and Food Deprivation in the EU Under Food Price Volatility and Rise', ULYSSES Policy Briefing 4, www.fp7-ulysses.eu/publications/ULYSSES $\% 20$ Policy $\% 20$ Brief $\% 204$ Analysis $\% 20$ of $\% 20$ material $\% 20$ and $\% 20$ food $\% 20$ deprivation $\% 20$ in $\% 20$ the $\% 20$ EU $\% 20$ under $\% 20$ food $\% 20$ 
price $\% 20$ volatility $\% 20$ and $\% 20$ rise.pdf (accessed 10 July 2015)

Ghosh, J. (2010) 'The Unnatural Coupling: Food and Global Finance', Fournal of Agrarian Change 10: 72-86

Gouel, C. (2013) Food Price Volatility and Domestic Stabilization Policies in Developing Countries, World Bank Policy Research Working Paper 6393, Washington DC: World Bank, https://openknowledge.worldbank.org/ bitstream/handle/10986/13186/wps6393.pdf (accessed 10 July 2015)

Greb, F.; Jamora, N.; Mengel, C.; von CramonTaubadel, S. and Würriehausen, N. (2012) Price Transmission from International to Domestic Markets, Courant Research Centre Discussion Paper 125, Göttingen: Georg-August-Universität, www2.vwl. wiso.uni-goettingen.de/courant-papers/CRGPEG_DP_125.pdf (accessed 10 July 2015)

Green, R.; Cornelsen, L.; Dangour, A.; Turner, R.; Shankar, B.; Mazzocchi, M. and Smith, R. (2013) 'The Effect of Rising Food Prices on Food Consumption: Systematic Review with Meta-regression', BM7 346:f3703, http://dx.doi. org/10.1136/bmj.f3703 (accessed 10 July 2015)

Headey, D. (2014) Food Prices and Poverty Reduction in the Long Run, IFPRI Discussion Paper 01331, Washington DC: International Food Policy Research Institute, www.ifpri.org/publication/ food-prices-and-poverty-reduction-long-run (accessed 10 July 2015)

HLPE (2013) Biofuels and Food Security. A Report by the High Level Panel of Experts on Food Security and Nutrition of the Committee on World Food Security, Rome 2013, Food and Agriculture Organization, www.fao.org/fileadmin/user_upload/hlpe/hlpe_ documents/HLPE_Reports/HLPE-Report-5_ Biofuels_and_food_security.pdf (accessed 10 July 2015)

IFPRI (2015) Excessive Food Price Variability Early Warning System, IFPRI-FSP, www.foodsecurityportal. org/policy-analysis-tools/excessive-food-pricevariability-early-warning-system (accessed 10 July 2015)

ILO (International Labour Organization) (2015)

\section{LABORSTA Labour Statistics Database,} http://laborsta.ilo.org/ (accessed 10 July 2015)

Ivanic, M. and Martin W. (2014) Short- and Long-Run Impacts of Food Price Changes on Poverty, World Bank Policy Research Working Paper 7011, Washington DC: World Bank, www-wds.worldbank.org/ external/default/WDSContentServer/WDSP/ IB/2014/08/20/000158349_20140820111849/ Rendered/PDF/WPS7011.pdf (accessed 10 July 2015)
Lee, B.; Preston, F.; Kooroshy, J.; Bailey, R. and Lahn, G. (2012) Resource Futures, London: Chatham House, http://resourcesfutures.org/ downloads/CHJ204_Resources_Futures_ WEB_28.01.13.pdf (accessed 10 July 2015) Magrini, E.; Opazo, C. and Balié, J. (2015) 'Price Shocks, Volatility and Household Welfare: A Cross-Country Inquiry', ULYSSES Policy Briefing 5, Madrid: ULYSSES, www.fp7-ulysses. eu/publications/ULYSSES $\% 20$ Policy $\% 20$ Brief $\% 205 \_$Price $\% 20$ Shocks, $\% 20$ Volatility $\% 20$ and $\% 20$ Household $\% 20$ Welfare $\% 20 \mathrm{~A} \% 20$ CrossCountry\%20Inquiry.pdf (accessed 10 July 2015)

Minot, N. (2012) Food Price Volatility in Africa: Has it Really Increased?, IFPRI Discussion Paper 01239, Washington DC: International Food Policy Research Institute, www.ifpri.org/sites/default/ files/publications/ifpridp01239.pdf (accessed 10 July 2015)

Naylor, R. and Falcon, W. (2010) 'Food Security in an Era of Economic Volatility', Population and Development Review 36.4: 693-723

Oxfam (2011) Growing a Better Future: Food Fustice in a Resource-constrained World, Oxfam International, http://policy-practice.oxfam.org.uk/publications/ growing-a-better-future-food-justice-in-a-resourceconstrained-world-132373 (accessed 10 July 2015)

Pinstrup-Anderson, P. (2015) 'How do Governments Respond to Food Price Volatility?', UNUWIDER Policy Brief 1.15, www.wider.unu.edu/ publications/policy-briefs/en_GB/pb1-2015/ (accessed 10 July 2015)

Spratt, S. (2013) Food Price Volatility and Financial Speculation, Future Agricultures Working Paper 47, Brighton: Future Agricultures Consortium, http://r4d.dfid.gov.uk/PDF/Outputs/ Futureagriculture/FAC_Working_Paper_047.pdf (accessed 10 July 2015)

Sumner, D. (2009) 'Recent Commodity Price Movements in Historical Perspective', American Fournal of Agricultural Economics 91.5: 1250-6

Wiggins, S. and Keats, S. (2013) Looking Back, Peering Forward: Food Prices and the Food Price Spike of 2007/08, London: Overseas Development Institute, www.odi.org/sites/odi.org.uk/files/ odi-assets/publications-opinion-files/8339.pdf (accessed 10 July 2015)

Wise, T. and Murphy, S. (2012) Resolving the Food Crisis: Assessing Global Policy Reforms Since 2007, Minneapolis: Institute for Agriculture and Trade Policy, and Medford: Global Development and Environment Institute (GDAE) at Tufts University, www.ase.tufts.edu/gdae/Pubs/rp/ ResolvingFoodCrisis.pdf (accessed 10 July 2015) 
World Bank (2015) World DataBank: Global Economic Monitor (GEM) Commodities, http://databank. worldbank.org/data/reports.aspx? source=globaleconomic-monitor-(gem) (accessed 10 July 2015)

World Bank (2012) Food Price Watch: August 2012, http://siteresources.worldbank.org/EXTPOVERTY/ Resources/336991-1311966520397/Food-PriceWatch-August-2012.htm (accessed 10 July 2015)

WFP (World Food Programme) (2015) The Market Monitor, www.wfp.org/content/market-monitor (accessed 10 July 2015)

Young Lives (2008) 'Children and the Food Price Crisis', Young Lives Policy Brief 5, Oxford: Department of International Development/ University of Oxford, www.younglives.org.uk/
publications/PP/children-food-price-crisis/ children-and-the-food-price-crisis (accessed 10 July 2015)

Zorya, S.; von Cramon-Taubadel, S.; Greb, F.; Jamora, N.; Mengel, C. and Würriehausen, N. (2014) 'Price Transmission from World to Local Grain Markets in Developing Countries: Why it Matters, How it Works, and How it Should be Enhanced', in I. Gillson and A. Fouad (eds), Trade Policy and Food Security: Improving Access to Food in Developing Countries in the Wake of High World Prices, Washington DC: World Bank, http://elibrary. worldbank.org/doi/abs/10.1596/978-1-46480305-5_ch3 (accessed 10 July 2015) 